\title{
Determinants of Student Performance at Secondary Level in Punjab
}

\author{
Dr. Khuda Bakhsh \\ Assistant Professor, Department of Education, GC University, Faisalabad \\ gallantup@yahoo.com \\ Dr. M. Naeem Mohsin \\ Head of the Education Department, GC University, Faisalabad \\ Dr. Shafqat Hussain \\ Assistant Professor, Department of Education, GC University, Faisalabad
}

Doi:10.5901/mjss.2015.v6n3s2p728

\begin{abstract}
The study explored certain factors influencing the student performance at secondary level in Punjab. A sample of five thousands teachers from one thousands schools participated in the study. The researcher developed a questionnaire to measure the determinants and student performance. The data was collected and entered into SPPS for data analysis. The analysis was made using regressions. The findings revealed that all the five selected variables significantly contribute to the student performance. The school climate proved to be the strongest determinant of student performance followed by his personal traits, teacher effectiveness, parenting and socio-economic status. Some potent recommendations were made on the basis of findings.
\end{abstract}

Keywords: Determinants, secondary School, Student Performance, Punjab, Regressions.

\section{Introduction}

The secondary school student in his teenage is just like a white paper ready to be written (Tanveer, 2014; Rubab,2005).These are the parents, society and school teachers who shape their future of the students. Learning environment and their socio-economic status also play a vital role to the academic excellence. It is obvious no one is born as zero but there is some genetic properties making them superior in their practical life (Adebisi, 2009). Naturally every child is fully fortified with all the required traits and skills excluding some special children (Frazzer, 2009).Soon after his birth, he is thoroughly dependent upon his parents. It is a pure natural phenomenon that the parents tend to look after him with due interest and pleasure. When he steps into his teen years, some social factors including hisneighbors, class fellows, social workers, family members positively or negatively lead him to do something right or wrong. On the basis of these deeds, he is liked or disliked by the society. Under the situation, when he is passing through his teen years, good parental involvement can make his early life joyful enriched with desired personality traits.

Education is the name of teaching-learning process. It is an interesting as well as difficult process at the same time (K.B.Khan, 2015). If the institution climate is conducive to the process enriched with student interest and teacher effectiveness then it is an enjoyable phenomenon otherwise the results show low academic achievement tending to failure (Fida, 2011; Azhar, 2013). The failure not only leads to heavy dropouts but also brings a life-long feeling of frustration and inferiority in the affected students (Olaye, 2013; Oyinla, 2012). The socio-economic status of the students enriched with personality traits positively supports the students to overcome the obstacles in the way of his education. The teacher effectiveness may change the life of his students to achieve their pre-determined goals (Craig, 2011).If a teacher is fully honest and result oriented, then he will surely predict good student performance.

\section{Statement of the Problem}

The problem to be investigated was how well certain factors taken as determinants contribute to the student performance as perceived by their teachers. 


\subsection{Research Questions}

In addressing our research problem, the following research questions were raised to be answered

1. What is the influence of each of independent variables on dependent variable?

2. What is the significant contribution of independent variables (school climate, parenting, socio-economic status, teacher effectiveness and personality traits) combined together on dependent variable (student performance)?

\section{Methodology}

\subsection{Population and sample of the study.}

The target population for the study was all the secondary school teachers working in Government High Schools (Male) of the Punjab province. A sample of five thousands teachers from one hundreds schools (randomly selected) participated in the study.

\subsection{Research Instrument}

The researcher developed and validated a questionnaire for the teachers to measure the variables taken as determinants and their student performance.

\subsection{Data Analysis}

The collected data was analyzed by SPSS (Statistical Package for the Social Sciences) and analyzed using stepwise and multiple regressions to answer the research questions. The research questions seeking how well certain factors/predictors individually and collectively contribute to the student performance were answered.

\section{Results}

\subsection{Research Question 1}

What is the significant contribution of each of independent variables on dependent variable? Individual contribution of school climate to the variance of Student Performance

Table 1. Linear Regression Analysis of school climate with the student performance

\begin{tabular}{|c|c|c|c|}
\hline R & R Square & Adjusted R Square & Std. Error of the Estimate \\
\hline .572 & .327 & .329 & 5.211 \\
\hline
\end{tabular}

Table 1 shows that school climate is a significant $\left(R^{2}=.327, p<.05\right)$ predictor of the student performance. This means that $32 \%$ of the variance in the student performance is influenced by school climate.

\section{$>$ Individual contribution of students' Personal Traits to the variance of their Performance}

Table 2: Linear regression analysis of Personal Traitswith student performance

\begin{tabular}{|c|c|c|c|}
\hline R & R Square & Adjusted R Square & Std. Error of the Estimate \\
\hline .512 & .262 & .279 & 6.147 \\
\hline
\end{tabular}

Table 2 shows that 26percent $\left(R^{2}=.262\right)$ of the student performance may be explained by their personal traits.

Table 3: Individual Contribution of 'Teacher Effectiveness' to the Student Performance

\begin{tabular}{|c|c|c|c|}
\hline R & R Square & Adjusted R Square & Std. Error of the Estimate \\
\hline .501 & .251 & .255 & 6.308 \\
\hline
\end{tabular}


Table 4: Individual Contribution of 'Parenting' to the student performance

\begin{tabular}{|c|c|c|c|}
\hline R & R Square & Adjusted R Square & Std. Error of the Estimate \\
\hline .407 & .166 & .165 & 6.714 \\
\hline
\end{tabular}

Table 5: Individual Contribution of 'Socio-Economic Status' to the student performance

\begin{tabular}{|c|c|c|c|}
\hline $\mathrm{R}$ & $\mathrm{R}$ Square & Adjusted R Square & Std. Error of the Estimate \\
\hline .332 & .110 & .105 & 6.155 \\
\hline
\end{tabular}

The Tables 1 to 5 clearly show the all the selected factors well determine the student performance with significant predictive powers. School climate, personal traits, teacher effectiveness, parenting and Socio-Economic Status contributed $32 \%, 26 \%, 25 \%, 16 \%$ and $11 \%$ respectively to the variance in student performance. The 'School Climate' proved to be best predictor $\left(\mathrm{R}^{2}=.320\right)$ followed by his personal traits, teacher effectiveness, parenting and socio-economic status.

\subsection{Research Question 2}

What is the significant contribution of independent variables (school climate, parenting, socio-economic status, teacher effectiveness and personality traits) combined together on dependent variable (student performance)?

Multiple Regression Analysis of the FIVE predictors with the academic achievement of secondary school students

Table 6: Combined Influence of all the predictors on the student performance

\begin{tabular}{|c|c|c|c|}
\hline R & R Square & Adjusted R Square & Std. Error of the Estimate \\
\hline .807 & .651 & .655 & 5.512 \\
\hline
\end{tabular}

Table 6 shows the joint influence of the all the FIVE factors was 65 percent to the variance in the academic achievement of the students. It may be seen easily these results that there are more predictors of academic performance need to be investigated in next studies in this regard.

\section{Conclusions}

It may be concluded from statistical findings that all the selected variables well determine the academic performance of secondary school students with significant predictive powers. The school climate proved to be strongest determinant of student performance followed by his personal traits, teacher effectiveness, parenting and socio-economic status. The climate conducive to teaching-learning process matters most in student performance. Next the student must be enriched with personal traits. The combined influence of all the five factors taken together accounted for $65 \%$ of the total variance student performance. It implies that the student performance is influenced by several other determinants to be investigated/hypothesized in next studies.

\section{Recommendations}

The student performance clearly reflects the moving picture of our education system and social values. Here the learning environment or school climate must be conducive to teaching-learning process. The climate must be safe and sound saturated with peace and happiness. The parents should satisfy all the needs and demands of their offspring completely. Parental involvement and supervision clearly predict the best performance of the teenagers. The student having high socio-economic status enjoying all the facilities is well developed. Each of his need is satisfied instantly and this leads to his good performance in each dimension of living life. The teachers must be honest with their profession and should use the required teaching strategies to make them more effective. Their effectiveness must be evaluated periodically by the education authorities and the parents. Some students possess personal traits naturally and are considered excellent in their studies. The other should have to develop such personality traits and skills as it is a potent determinant of their performance accessible by careful parenting and target oriented teachers. The parents excite their children to face the 
challenges of living life and provide the strongest foundation of their academic excellence.

\section{References}

Adebisi, A. (2009).The effect of academic performance and counseling on the choice of post-Secondary institution. The Counsellor. 5 (1), $1-11$

Azhar, A. (2013). Genetic Properties of horses.Aeeliya Publishers, Lukhno, India

Craig, A. (2011). Effective teaching and learning. London: University press Ltd.

Frazzer, E. (2009): Home environment and the School. London. London press.

Fida, H. (2001). Wealth and Health: A case study of diabetics patients. Al-Hadi Press, Tehran

K.B.Khan (2015).Determinants of Teacher Attrition at Secondary Level in Pakistan' in INTCESS15 -paper presented (virtual) in 2nd International Conference on Education and Social Sciences, February2-4, 2015-Istanbol

Olaoye, E.A. (2013): Factors affecting students' academic performance in secondary schools, Journal of Science 21(2), 43-50

Oyinlola, B. (2012): Predicting children educational achievement from father's occupation. Journal of Science Education. 21(2) 46-52

Rubab, Z. (2005). Personality Traits.Nauroz Publishers, Karachi

Tanveer.A. (2014). School Climate and Teacher Effectiveness: A case study of Zia Public High School, Sargodha 